University of Nebraska - Lincoln

DigitalCommons@University of Nebraska - Lincoln

\title{
Effect of Soybean Oil Fatty Acid Composition and Selenium Application on Biodiesel Properties
}

\author{
Benjamin D. Fallen \\ University of Tennessee, BFALLEN@clemson.edu \\ Vincent R. Pantalone \\ University of Tennessee, vpantalo@utk.edu \\ Carl E. Sams \\ University of Tennessee, carlsams@tennessee.edu \\ Dean A. Kopsell \\ University of Tennessee, dkopsell@utk.edu \\ Steven F. Vaughn \\ United States Department of Agriculture \\ See next page for additional authors
}

Follow this and additional works at: https://digitalcommons.unl.edu/usdaarsfacpub

Fallen, Benjamin D.; Pantalone, Vincent R.; Sams, Carl E.; Kopsell, Dean A.; Vaughn, Steven F.; and Moser, Bryan R., "Effect of Soybean Oil Fatty Acid Composition and Selenium Application on Biodiesel Properties" (2011). Publications from USDA-ARS / UNL Faculty. 1246.

https://digitalcommons.unl.edu/usdaarsfacpub/1246

This Article is brought to you for free and open access by the U.S. Department of Agriculture: Agricultural Research Service, Lincoln, Nebraska at DigitalCommons@University of Nebraska - Lincoln. It has been accepted for inclusion in Publications from USDA-ARS / UNL Faculty by an authorized administrator of DigitalCommons@University of Nebraska - Lincoln. 


\section{Authors}

Benjamin D. Fallen, Vincent R. Pantalone, Carl E. Sams, Dean A. Kopsell, Steven F. Vaughn, and Bryan R. Moser 


\title{
Effect of Soybean Oil Fatty Acid Composition and Selenium Application on Biodiesel Properties
}

\author{
Benjamin D. Fallen • Vincent R. Pantalone • \\ Carl E. Sams • Dean A. Kopsell • \\ Steven F. Vaughn $\cdot$ Bryan R. Moser
}

This article is a U.S. government work, and is not subject to copyright in the United States.

Received: 26 April 2010/Revised: 18 November 2010/Accepted: 2 December 2010/Published online: 2 February 2011

(C) AOCS 2011

\begin{abstract}
Biodiesel consisting principally of monounsaturated fatty acid methyl esters (FAME) has been reported to have the optimal balance between cold flow properties and oxidative stability, therefore producing a superior fuel. In addition, treating biodiesel with antioxidants such as selenium (Se) also increases oxidative stability. Fuel properties including acid value (AV), cloud point (CP), iodine value (IV), pour point (PP), peroxide value (PV), induction period (IP), onset temperature (OT), and kinematic viscosity (KV) were used to evaluate a newly developed Roundup Ready ${ }^{\circledR}$ soybean recombinant inbred line (RIL) and a commercial cultivar. The RIL had a fatty acid profile with elevated levels of monounsaturated FAME. TN07-93RR was determined as the more desirable line for production of biodiesel, based on its fatty acid composition and subsequent fuel properties. The commercial cultivar AG3906 contained the highest abundance of polyunsaturated FAME and exhibited comparatively high IV and low oxidative stability. AG3906 was therefore not acceptable under the European biodiesel standard, EN 14214. However, TN07-93RR and AG3906 both were
\end{abstract}

Product names are necessary to report factually on available data; however, the USDA neither guarantees nor warrants the standard of the product, and the use of the name by USDA implies no approval of the product to the exclusion of others that may also be suitable.

B. D. Fallen · V. R. Pantalone $(\varangle) \cdot$ C. E. Sams · D. A. Kopsell Department of Plant Sciences, University of Tennessee,

2431 Joe Johnson Dr, Knoxville, TN 37996, USA

e-mail: vpantalo@utk.edu

S. F. Vaughn · B. R. Moser

United States Department of Agriculture,

Agricultural Research Service,

National Center for Agricultural Utilization Research,

1815 N. University St Peoria, Peoria, IL 61604, USA considered satisfactory according to the American biodiesel standard, ASTM D6751. Foliar treatment of soybean plants with varying amounts of Se had no effect on subsequent biodiesel oxidative stabilities.

Keywords Biodiesel - Cloud point · Fatty acid methyl esters · Induction period - Oxidative stability - Pour point . Soybean oil $\cdot$ Selenium

$\begin{array}{ll}\text { Abbreviations } \\ \text { AV } & \text { Acid value } \\ \text { CP } & \text { Cloud point } \\ \text { FAME } & \text { Fatty acid methyl ester(s) } \\ \text { KV } & \text { Kinematic viscosity } \\ \text { IP } & \text { Induction period } \\ \text { IV } & \text { Iodine value } \\ \text { OT } & \text { Onset temperature } \\ \text { PV } & \text { Peroxide value } \\ \text { PP } & \text { Pour point } \\ \text { RIL } & \text { Recombinant inbred line } \\ \text { Se } & \text { Selenium } \\ \text { SME } & \text { Soybean methyl ester }\end{array}$

\section{Introduction}

Biodiesel must be satisfactory according to accepted fuel standards (Table 1) such as ASTM D6751 in the United States or the Committee for Standardization (CEN) standard EN 14214 in Europe before it can be used in compression-ignition (diesel) engines. The fatty acid methyl esters (FAME) composition, along with the presence of contaminants and minor components, determines fuel 
Table 1 Selected specifications from ASTM D6751 and EN 14214 biodiesel fuel standards

\begin{tabular}{|c|c|c|}
\hline & ASTM D6751 & EN 14214 \\
\hline Acid value $\left(\mathrm{mg} \mathrm{KOH} \mathrm{g}^{-1}\right)$ & $0.50 \max$ & $0.50 \max$ \\
\hline Cloud point $\left({ }^{\circ} \mathrm{C}\right)$ & Report & - \\
\hline Pour point $\left({ }^{\circ} \mathrm{C}\right)$ & - & - \\
\hline \multicolumn{3}{|l|}{ Oxidative stability } \\
\hline Induction period $\left(110^{\circ} \mathrm{C}, \mathrm{h}\right)$ & $3 \min$ & $6 \mathrm{~min}$ \\
\hline Onset temperature $\left({ }^{\circ} \mathrm{C}\right)$ & - & - \\
\hline Kinematic viscosity, $40^{\circ} \mathrm{C}\left(\mathrm{mm}^{2} \mathrm{~s}^{-1}\right)$ & $1.9-6.0$ & $3.5-5.0$ \\
\hline Peroxide value (mequiv $\mathrm{kg}^{-1}$ ) & - & - \\
\hline Iodine value $\left(\mathrm{g} \mathrm{I}_{2} 100 \mathrm{~g}^{-1}\right)$ & - & $120 \max$ \\
\hline
\end{tabular}

max maximum, min minimum, -: not specified

properties of biodiesel fuel [1-3]. Because each feedstock has a unique chemical composition, biodiesel produced from different feedstocks will in turn have different fuel properties. Important properties of biodiesel that are directly influenced by FAME composition include low temperature operability, oxidative and storage stability, kinematic viscosity (KV), exhaust emissions, cetane number, and energy content [1-3]. The two properties emphasized in the discussion below will be low temperature operability and oxidative stability, as biodiesel is generally considered to be technically deficient with regard to these properties versus conventional petroleum-derived diesel fuel [1-3]. Additionally, relatively minor modifications of FAME composition can result in dramatic changes in the oxidative stability and low temperature properties of biodiesel [1-3].

Structural features such as chain length, degree of unsaturation, double bond geometry and type of ester head group strongly influence cold flow properties of biodiesel $[1,2]$. Low temperature operability is normally determined by cloud point (CP) (ASTM D2500 or D5773), pour point (PP) (ASTM D97 or D5949), cold filter plugging point (CFPP; ASTM D6371), and/or the low temperature flow test (LTFT; ASTM D4539). The American biodiesel standard, ASTM D6751 (Table 1), requires that CP be reported but does not specify a maximum limit. The European biodiesel standard, EN 14214 (Table 1), specifies limits for CFPP, which are variable according to location and time of year.

Oxidation initiates, in the case of biodiesel, at methylene carbons allylic to sites of unsaturation [3, 4]. Autoxidation of biodiesel produces free radicals through hydrogen abstraction in the presence of various initiators such as light, heat, peroxides, hydroperoxides, and transition metals. These free radicals further react exothermically with molecular oxygen to produce peroxides, which react with un-oxidized biodiesel to produce additional free radicals [4]. Generally, the rate limiting step in the autoxidation of lipids is initial hydrogen abstraction. Many naturally occurring flavonoids in plants confer stability against autoxidation to vegetable oils. The effectiveness of flavonoids in retarding lipid oxidation in fat-containing foods is related to their ability to act as free-radical acceptors [5]. Not only does the high oxidative reactivity compromise the use of soybean oil as biodiesel, but also as a vegetable oil for human consumption. Synthetic antioxidants often have to be added to soybean oil to retard oxidation of unsaturated fatty acids and to decrease the development of rancidity. This method can be costly and unhealthy.

One of the objectives of this study was to evaluate the fuel properties of biodiesel prepared from a commercial soybean variety with a Roundup ${ }^{\circledR}$ Ready $\mathrm{F}_{6: 9}$ increased oleic acid soybean line, TN07-93RR, which has been proven to yield competitively with commercially available soybean varieties and exhibit other desirable agronomic traits [6]. Fuel properties of interest in this study included $\mathrm{CP}$, PP, oxidative stability, $\mathrm{KV}$, iodine value (IV), and peroxide value $(\mathrm{PV})$.

A further objective was to apply Se to soybeans at the flowering and seed development stages in an effort to improve the oxidative stability of the resultant biodiesel. Se was chosen due not only to its potential antioxidant properties for soybean oil [7], but also added health benefits for both animals and humans. Se is an integral component of glutathione peroxidase, an important antioxidative enzyme that inhibits the oxidation of lipid membranes by free radicals, thus preventing oxidative stress which can lead to inflammation, atherosclerosis and cardiovascular diseases. The Se requirement for most farm animals is between 0.1 and $0.3 \mathrm{mg} \mathrm{kg}^{-1}$ of feed. The recommended daily intake for human adults is $50 \mu \mathrm{g} \mathrm{day}^{-1}$ and for children it is $20-30 \mu \mathrm{g} \mathrm{day}^{-1}$ [8]. The Se concentration in plants depends on the chemical form of Se, its concentration, bioavailability and the accumulation capacity of the plant. Zhang [9] concluded from foliar applications of selenite and selenate that selenate is somewhat more effective than selenite and that the effect depends on the stage of development of the crop at the time of spraying.

\section{Experimental Procedures}

\section{Materials}

Plant material used in this study were derived from crosses made between Roundup ${ }^{\circledR}$ Ready early generation lines from which USG 'Allen' (UniSouth Genetics, Inc., Nashville, TN) was later derived () and early generation lines 
from which N98-4445A was later derived ( $\widehat{0})$. The germplasm N98-4445A was developed by the USDA-ARS in cooperation with the North Carolina Agriculture Research Service at NC State University [10]. N98-4445A has an oleic acid concentration of approximately $560 \mathrm{~g} \mathrm{~kg}^{-1}$. This concentration is around $340-380 \mathrm{~g} \mathrm{~kg}^{-1}$ greater (i.e., nearly $3 \times$ ) than the oleic acid concentration in commercial soybean cultivars. Allen is a Roundup ${ }^{\circledR}$ Ready variety developed at the University of Tennessee. The agronomic stability of Allen has been well documented, as it was one of the top performing cultivars for its maturity class in the Roundup ${ }^{\circledR}$ Ready Tennessee State Variety Tests during the 2006 and 2008 growing seasons, and was the top performing cultivar in 2007.

In this study, the pedigree-selection procedure was used to select single plants based on oleic acid content obtained using gas chromatography $(\mathrm{GC})$ until the $\mathrm{F}_{6: 8}$ generation. In 2007, the selected soybean genotypes were entered into preliminary yield trials (PYTs) in Knoxville, TN. In 2008, the Roundup ${ }^{\circledR}$ Ready $\mathrm{F}_{6: 9}$ line exhibiting the highest oleic acid concentration (TN07-93RR) and a commercial check (AG3906, obtained from Asgrow Company) were grown across Tennessee. The three locations included: East Tennessee Research and Education Center (Knoxville, TN), the Highland Rim Research and Education Center (Springfield, TN), and the Research and Education Center at Milan (Milan, TN) representing major physiographic regions of East Tennessee, Middle Tennessee, and West Tennessee. The soil type at Knoxville, Springfield and Milan was a Sequatchie silt loam (fine-loamy, siliceous, thermic, Himuc Hapludults), Dickson silt loam (fine-silty, siliceous, semi-active, thermic Glossic Fragiudults) and Collins silt loam (coarsesilty, mixed, active, acid thermic Aquic Udifluvents), respectively. The experiment was conducted in a randomized complete block design with a factorial treatment arrangement and replication. At Knoxville and Springfield each line was seeded in four rows $6.1 \mathrm{~m}$ long with $76 \mathrm{~cm}$ spacing between rows. At Milan each line was seeded in four rows $9.1 \mathrm{~m}$ long with $76 \mathrm{~cm}$ spacing. Experiments were planted in late May and the two center rows were harvested in late September.

FAME standards were purchased from Nu-Chek Prep, Inc. (Elysian, MN). All other chemicals and reagents were obtained from Sigma-Aldrich Corp. (St. Louis, MO) and used as received. Due to time constraints and cost, only the untreated control and the high Se treatment for both the increased oleic acid soybean (TN07-93RR) and the commercial check (AG3906) were tested according to ASTM standards. PP, CP, KV, induction period (IP), onset temperature (OT), acid value (AV), PV and fatty acid quantification by GC were run in triplicate and average values are reported.
Extraction of Soybean Oil

Soybean samples were ground in a coffee grinder and oil was extracted with hexane for $24 \mathrm{~h}$ in a Soxhlet apparatus. Hexane was removed from the oil by rotary evaporation under reduced pressure $\left(20 \mathrm{mbar} ; 30^{\circ} \mathrm{C}\right)$ [11].

\section{Methanolysis of Soybean Oil}

Methanolysis of soybean oil samples was performed in a 250-mL three-necked round bottom flask connected to a reflux condenser and a mechanical magnetic stirring/heating plate set at 1,200 rpm. Initially, soybean oil samples $(100 \mathrm{~g}, 0.102 \mathrm{~mol})$ and methanol $(25 \mathrm{~mL}, 0.61 \mathrm{~mol}$; 6:1 mol ratio) were added to the flask and heated to $60{ }^{\circ} \mathrm{C}$ (internal reaction temperature monitored by digital temperature probe), followed by addition of $0.50 \mathrm{wt} \%$ sodium methoxide ( $25 \mathrm{wt} \%$ in methanol). After reacting for $1.5 \mathrm{~h}$ the mixture was equilibrated to room temperature and transferred to a separatory funnel. The lower glycerol phase was removed by gravity separation ( $>2 \mathrm{~h}$ settling time) followed by removal of methanol from the crude methyl ester phase by reduced pressure $\left(20 \mathrm{mbar} ; 30^{\circ} \mathrm{C}\right)$ rotary evaporation. The crude methyl esters were washed until a neutral $\mathrm{pH}$ was obtained with distilled water $(4 \times 20 \mathrm{~mL})$ and dried with magnesium sulfate to provide soybean oil methyl esters (SME) [12, 13].

\section{Fatty Acid Quantification by GC}

FAME of soybean oil were prepared according to AOCS Ce 2-66 using methanolic $\mathrm{KOH}$ and separated [14] using a Varian (Walnut Creek, CA) 8400 GC equipped with an FID detector and a SP2380 (Supelco, Bellefonte, PA) column $(30 \mathrm{~m} \times 0.25 \mathrm{~mm}$ i.d., $0.20 \mu \mathrm{m}$ film thickness). The carrier gas was $\mathrm{He}$ at $1 \mathrm{~mL} \mathrm{~min}^{-1}$. The oven temperature was initially held at $150{ }^{\circ} \mathrm{C}$ for $15 \mathrm{~min}$, increased to $210{ }^{\circ} \mathrm{C}$ at $2{ }^{\circ} \mathrm{C} \mathrm{min}-1$, increased to $220{ }^{\circ} \mathrm{C}$ at $50{ }^{\circ} \mathrm{C}$ $\min ^{-1}$, then held for $10 \mathrm{~min}$. The injector and detector temperatures were 240 and $270{ }^{\circ} \mathrm{C}$, respectively. FAME peaks were identified by comparison to the retention times of reference standards $[14,15]$.

\section{${ }^{1}$ H-NMR and FT-IR Spectroscopy}

Proton Nuclear Magnetic Resonance ( ${ }^{1} \mathrm{H}$ NMR) data were recorded using a Bruker AV-500 spectrometer (Billerica, MA) operating at $500 \mathrm{MHz}$ using a $5-\mathrm{mm}$ broadband inverse Z-gradient probe in $\mathrm{CDCl}_{3}$ (Cambridge Isotope Laboratories, Andover, MA) as a solvent. Fourier Transform Infrared Spectroscopy (FT-IR) spectra were recorded on a Thermo-Nicolet Nexus 470 FTIR spectrometer (Madison, WI) with a Smart ARK accessory containing a 
$45 \mathrm{ZeSe}$ trough in a scanning range of $650-4,000 \mathrm{~cm}^{-1}$ for 64 scans at a spectral resolution of $4 \mathrm{~cm}^{-1}$ [16].

\section{Low Temperature Operability}

The CP is defined as the temperature at which crystal growth is large enough (diameter $\geq 0.5 \mu \mathrm{m}$ ) to be visible to the naked eye [3]. At temperatures below the CP, larger crystals fuse together and form agglomerations that eventually become extensive enough to prevent pouring of the fluid. The lowest temperature at which the fluid will pour is defined as the PP [3]. The CFPP test method calls for cooling a sample at a specified rate and drawing it under a vacuum through a wire mesh filter. CFPP is defined as the lowest temperature at which $20 \mathrm{~mL}$ of fluid safely passes through the filter within $60 \mathrm{~s}$ [3]. Similar to CFPP but less user friendly, LTFT is the lowest temperature at which $180 \mathrm{~mL}$ of fluid safely passes through a filter within $60 \mathrm{~s}$ [3].

$\mathrm{CP}$ and PP determinations were made in agreement with ASTM D5773 [17] and ASTM D5949 [18], respectively, using a Phase Technology Analyzer model PSA-70S (Richmond, B C, Canada). CP and PP were rounded to the nearest whole degree $\left({ }^{\circ} \mathrm{C}\right)$. For a greater degree of accuracy, PP measurements were done with a resolution of $1{ }^{\circ} \mathrm{C}$ instead of the specified $3{ }^{\circ} \mathrm{C}$ increment.

\section{Kinematic Viscosity}

$\mathrm{KV}\left(v, \mathrm{~mm}^{2} \mathrm{~s}^{-1}\right)$ was determined with a Cannon-Fenske viscometer (Cannon Instrument Co., State College, PA) at $40{ }^{\circ} \mathrm{C}$ in accordance with ASTM D445 [19].

\section{Oxidative Stability}

IP(h) was measured in accordance with EN 14112 [20] utilizing a Metrohm USA, Inc. (Riverview, FL) model 743 Rancimat instrument. IP was mathematically determined as the inflection point of a computer-generated plot of conductivity $\left(\mu \mathrm{S} \mathrm{cm}^{-1}\right)$ of deionized water versus time (h).

OT $\left({ }^{\circ} \mathrm{C}\right)$ was determined using a DSC 2910 thermal analyzer from TA Instruments (Newcastle, DE). Typically, a $2-\mu \mathrm{L}$ sample, resulting in a film thickness of $<1 \mathrm{~mm}$, was placed in an aluminum pan hermetically sealed with a pinhole lid and oxidized with pressurized $(1,378.95 \mathrm{kPa} ; 200 \mathrm{psi})$ dry air (Gateway Airgas, St. Louis, MO) in the module with a heating rate of $10{ }^{\circ} \mathrm{C} \mathrm{min}{ }^{-1}$ from 50 to $350{ }^{\circ} \mathrm{C}$. A computergenerated plot of heat flow $\left(\mathrm{W} \mathrm{g} \mathrm{g}^{-1}\right)$ versus temperature $\left({ }^{\circ} \mathrm{C}\right)$ was used to graphically determine OT [20].

Acid, Iodine and Peroxide Values

The AV is defined as the number of mg of $\mathrm{KOH}$ necessary to neutralize the free acids present in $1 \mathrm{~g}$ of fat or oil. AV $\left(\mathrm{mg} \mathrm{KOH} \mathrm{g}^{-1}\right)$ titrations were performed as described in AOCS official method Cd 3d-63 [21] using a Metrohm 836 Titrando (Westbury, NY) autotitrator equipped with a model 801 stirrer, a Metrohm 6.0229.100 Solvotrode, and Tiamo 1.1 Light software. However, the official method was modified for scale to use 2 -g samples and $0.02 \mathrm{M} \mathrm{KOH}$. The titration endpoint was determined by the instrument and visually verified using a phenolphthalein indicator.

The IV was calculated from the fatty acid profile according to AOCS official method 1c-85 [22].

The PV (mequiv of peroxide $\mathrm{kg}^{-1}$ sample) was determined using the modified ferric thiocyanate method of Shantha and Decker [23]. Hydroperoxides were calculated using a standard curve made from solutions of ferric chloride $\left(0-15 \mu \mathrm{Fe}^{3+}\right)$.

\section{Selenium Applications}

Sodium selenate foliar application [24] concentrations were 0 (control), 3 (low), 6 (medium), and $12 \mathrm{mg} \mathrm{L}^{-1}$ (high). Experimental design was a randomized complete block design with a factorial arrangement of treatments, including a non-treated control for comparison. Each treatment was replicated three times. Applications were made with a compressed-air sprayer calibrated to deliver $654 \mathrm{~L} \mathrm{ha}^{-1}$ at $344 \mathrm{kPa}$ and a nonionic surfactant was applied at $0.25 \% \mathrm{v} / \mathrm{v}$ with each Se application. Applications were made twice, once at flowering (R1) and again at seed development (R5).

\section{Elemental Analysis}

To determine the Se concentration in the meal, a ground 0.3 -g meal sample was mixed with $10.0 \mathrm{~mL}$ of $70 \%$ concentrated nitric acid $\left(\mathrm{HNO}_{3}\right)$ and digested in a microwave accelerated reaction system (MARS5, CEM Corp., Matthews, NC). Digestion procedures followed those for organically based matrices [25]. The digested solution was cooled to room temperature and $0.1 \mathrm{~mL}$ of the solution was added to $9.9 \mathrm{~mL}$ solution of reverse osmosis (Ro) $\mathrm{H}_{2} \mathrm{O}, 2 \%$ $\mathrm{HNO}_{3}$ and $0.5 \%$ hydrochloric acid (HCL) to give a final volume of $10.0 \mathrm{~mL}$. Elemental analysis was determined by ICP-MS (Inductively Coupled Plasma-Mass Spectrometry; 7500, Agilent Technologies Inc., Wilmington, DE) [24].

To determine the Se concentration in the oil, a ground 0.5-g meal sample was mixed with $1 \mathrm{~mL}$ extraction solvent consisting of an 8:5:2( $(\mathrm{v} / \mathrm{v} / \mathrm{v})$ ratio of chloroform, hexane and methanol and allowed to set overnight. Any remaining solvent was evaporated using a nitrogen evaporator (Meyer N-EVAP, Organomation Associates Inc., Berlin, MA). Then the oil was extracted from the sample and digested using $10.0 \mathrm{~mL}$ of $70 \% \mathrm{HNO}_{3}$ and allowed to set overnight. Then, $0.1 \mathrm{~mL}$ of the digested solution was added to $9.9 \mathrm{~mL}$ 
solution of $\mathrm{Ro}_{2} \mathrm{O}, 2 \% \mathrm{HNO}_{3}$ and $0.5 \% \mathrm{HCL}$ to give a final volume of $10.0 \mathrm{~mL}$. Elemental analysis was determined by ICP-MS (Inductively Coupled Plasma - Mass Spectrometry; 7,500, Agilent Technologies Inc., Wilmington, DE) [24].

\section{Results and Discussion}

\section{Fatty Acid Composition}

The soybean oil samples in this study contained the following fatty acids in varying amounts (Tables $2,3,4$ ): myristic acid (C14:0), palmitic acid (C16:0), palmitoleic acid (C16:1), stearic acid (C18:0), oleic acid (C18:1), linoleic acid (C18:2), linolenic acid (C18:3), arachidic acid (C20:0), gondoic acid (C20:1), and behenic acid (C22:0). Typically, soybean oil primarily contains $\mathrm{C} 16: 0(\sim 11 \%)$, $\mathrm{C} 18: 0(\sim 4 \%), \quad \mathrm{C} 18: 1(\sim 24 \%), \quad \mathrm{C} 18: 2(\sim 54 \%), \quad$ and C18:3( $\sim 7 \%)$, with trace amounts of other constituents also present [26].

While there were significant differences among the genotypes $(P<0.0001)$ for oleic acid, linoleic acid, and linolenic acid concentration (Table 2), there were no differences among Se treatments within each genotype or averaged over all genotypes $(P>0.05)$ for fatty acid composition (Tables 3, 4). TN07-93RR averaged 36.1\% oleic acid (C18:1) and 3.2\% linolenic acid (C18:3), while AG3906 averaged $23.5 \%$ oleic acid (C18:1) and 7.2\% linolenic acid (C18:3). TN07-93RR averaged a 54\% increase in oleic acid (C18:1) and 56\% decrease in linolenic acid (C18:3), compared with AG3906. No significant differences in fatty acid composition were observed among Se treatments in TN07-93RR or AG3906.

\section{Preparation of Soybean Oil Methyl Esters}

SME samples were prepared in high yield ( $>90 \mathrm{wt} \%$ ) from crude soybean oil. The quality of the methyl esters produced in each sample was verified through determination of AV (Tables 5, 6, 7), ${ }^{1} \mathrm{H}-\mathrm{NMR}$ and FT-IR.

Measures of fat acidity normally reflect the amount of fatty acids hydrolyzed from triacylglycerols. As can be seen, all samples provided results that were substantially below the maximum allowable limits $\left(0.50 \mathrm{mg} \mathrm{KOH} \mathrm{g}^{-1}\right.$ or less) prescribed in the ASTM D6751 and EN 14214 biodiesel standards. The ${ }^{1} \mathrm{H}-\mathrm{NMR}$ (Fig. 1) and FT-IR spectra (data not shown) of the various SME samples were qualitatively indistinguishable and comparable to those previously reported $[12,27]$. The various SME samples, although having different fatty acid profiles, contained identical functional groups (methyl esters, olefinic, allylic, bis-allylic, methylene, and terminal methyl groups), thus resulting in similar ${ }^{1} \mathrm{H}-\mathrm{NMR}$ and FT-IR spectra. For example, all SME samples contained methyl ester moieties that were prominently indicated in ${ }^{1} \mathrm{H}-\mathrm{NMR}$ spectra by strong singlets at $\delta 3.67 \mathrm{ppm}$ (Fig. 1) and in FT-IR spectra by prominent carbonyl signals at $1,742 \mathrm{~cm}^{-1}$.

\section{Fuel Properties}

Higher IP values are considered more desirable, as they are indicative of superior oxidative stability. Measurement of IP allows a comparison of oxidative stability because it provides an indication of the amount of lipid oxidation that has occurred in each sample [1]. AG3906 was characterized as having the highest content of polyunsaturated FAME tested (58 wt\%; Table 2), which was responsible for the high IV and low IP. In addition, AG3906 contained the highest abundance of linolenic acid (C18:3; $7.2 \mathrm{wt} \%$; Table 2), which simultaneously caused disproportionate increases in IV and decreases in IP versus other FAME. The deleterious relationship between polyunsaturated FAME content and IP is further demonstrated by Fig. 2, which indicated an inverse relationship between these parameters with an $R^{2}$ value of 0.722 . Taking into consideration the more stringent EN 14214 biodiesel standard when evaluating TN07-93RR and AG3906, specifications such as IV

Table 2 Descriptive statistics of mean fatty acid composition by genotype for TN07-93RR and AG3906 grown in Milan, TN, Springfield, TN, and Knoxville, TN in 2008 under two sodium selenate treatments: $0 \mathrm{mg} \mathrm{L}^{-1}$ (control) and $12 \mathrm{mg} \mathrm{L}^{-1}$ (high)

\begin{tabular}{llllllllllllll}
\hline Genotype & $\mathrm{C} 14: 0$ & $\mathrm{C} 16: 0$ & $\mathrm{C} 16: 1$ & $\mathrm{C} 18: 0$ & $\mathrm{C} 18: 1$ & $\mathrm{C} 18: 2$ & $\mathrm{C} 18: 3$ & $\mathrm{C} 20: 0$ & $\mathrm{C} 20: 1$ & $\mathrm{C} 22: 0$ & $\Sigma$ sat & $\Sigma$ monounsat & $\Sigma$ polyunsat \\
\hline AG3906 & 0.1 & 10.9 & 0.1 & 5.0 & 23.5 & 51.0 & 7.2 & 0.4 & 0.1 & 0.3 & 16.7 & 25.2 & 58.2 \\
TN07-93RR & 0.1 & 10.8 & 0.1 & 4.7 & 36.1 & 42.3 & 3.2 & 0.5 & 0.2 & 0.4 & 16.5 & 38.0 & 45.5 \\
LSD $_{0.05}$ & $\mathrm{~ns}$ & $\mathrm{~ns}$ & $\mathrm{~ns}$ & $\mathrm{~ns}$ & 0.8 & 0.7 & 0.1 & $\mathrm{~ns}$ & $\mathrm{~ns}$ & 0.1 & $\mathrm{~ns}$ & 0.7 & 0.8 \\
\hline
\end{tabular}

$\Sigma$ sat $=\mathrm{C} 14: 0+\mathrm{C} 16: 0+\mathrm{C} 18: 0+\mathrm{C} 20: 0+\mathrm{C} 22: 0$

$\Sigma$ monounsat $=\mathrm{C} 16: 1+\mathrm{C} 18: 1+\mathrm{C} 20: 1$

$\Sigma$ polyunsat $=\mathrm{C} 18: 2+\mathrm{C} 18: 3$

$\mathrm{LSD}_{0.05}$, Least significance difference at the 0.05 probability level

ns, non-significant 
Table 3 Descriptive statistics of mean fatty acid composition by genotype for TN07-93RR and AG3906 grown in Milan, TN, Springfield, TN, and Knoxville, TN in 2008 under two sodium selenate treatments: $0 \mathrm{mg} \mathrm{L}^{-1}$ (control) and $12 \mathrm{mg} \mathrm{L}^{-1}$ (high)

\begin{tabular}{|c|c|c|c|c|c|c|c|c|c|c|c|c|c|c|}
\hline Treatment & Genotype & C14:0 & C16:0 & $\mathrm{C} 16: 1$ & C18:0 & C18:1 & C18:2 & C18:3 & C20:0 & C20:1 & C22:0 & $\Sigma$ sat & $\Sigma$ monounsat & $\Sigma$ polyunsat \\
\hline Control & AG3906 & 0.1 & 10.9 & 0.1 & 5.0 & 23.5 & 51.0 & 7.2 & 0.3 & 0.1 & 0.3 & 16.6 & 25.2 & 58.2 \\
\hline High & AG3906 & 0.1 & 10.9 & 0.1 & 5.0 & 23.5 & 50.9 & 7.2 & 0.4 & 0.1 & 0.3 & 16.7 & 25.2 & 58.1 \\
\hline Control & TN07-93RR & 0.1 & 10.9 & 0.1 & 4.7 & 36.2 & 42.1 & 3.2 & 0.5 & 0.2 & 0.4 & 16.6 & 38.2 & 45.2 \\
\hline High & TN07-93RR & 0.1 & 10.7 & 0.1 & 4.7 & 35.9 & 42.6 & 3.1 & 0.5 & 0.2 & 0.4 & 16.4 & 37.9 & 45.7 \\
\hline $\mathrm{LSD}_{0.05}$ & - & ns & ns & ns & ns & ns & ns & ns & ns & ns & ns & ns & ns & ns \\
\hline
\end{tabular}

$\Sigma$ sat $=\mathrm{C} 14: 0+\mathrm{C} 16: 0+\mathrm{C} 18: 0+\mathrm{C} 20: 0+\mathrm{C} 22: 0$

$\Sigma$ monounsat $=\mathrm{C} 16: 1+\mathrm{C} 18: 1+\mathrm{C} 20: 1$

$\Sigma$ polyunsat $=\mathrm{C} 18: 2+\mathrm{C} 18: 3$

$\mathrm{LSD}_{0.05}$, Least significance difference at the 0.05 probability level ns, non-significant

Table 4 Descriptive statistics of mean fatty acid composition by treatment for TN07-93RR and AG3906 grown in Milan, TN, Springfield, TN, and Knoxville, TN in 2008 under two sodium selenate treatments: $0 \mathrm{mg} \mathrm{L}^{-1}$ (control) and $12 \mathrm{mg} \mathrm{L}^{-1}$ (high)

\begin{tabular}{llllllllllllll}
\hline Treatment & $\mathrm{C} 14: 0$ & $\mathrm{C} 16: 0$ & $\mathrm{C} 16: 1$ & $\mathrm{C} 18: 0$ & $\mathrm{C} 18: 1$ & $\mathrm{C} 18: 2$ & $\mathrm{C} 18: 3$ & $\mathrm{C} 20: 0$ & $\mathrm{C} 20: 1$ & $\mathrm{C} 22: 0$ & $\Sigma$ sat & $\Sigma$ monounsat & $\Sigma$ polyunsat \\
\hline Control & 0.1 & 10.9 & 0.1 & 4.8 & 29.9 & 46.5 & 5.2 & 0.4 & 0.2 & 0.4 & 16.6 & 31.7 & 51.7 \\
High & 0.1 & 10.8 & 0.1 & 4.9 & 29.7 & 46.8 & 5.2 & 0.4 & 0.2 & 0.4 & 16.6 & 31.5 & 51.9 \\
LSD $_{0.05}$ & $\mathrm{~ns}$ & $\mathrm{~ns}$ & $\mathrm{~ns}$ & $\mathrm{~ns}$ & $\mathrm{~ns}$ & $\mathrm{~ns}$ & $\mathrm{~ns}$ & $\mathrm{~ns}$ & $\mathrm{~ns}$ & $\mathrm{~ns}$ & $\mathrm{~ns}$ & $\mathrm{~ns}$ & $\mathrm{~ns}$ \\
\hline
\end{tabular}

$\Sigma$ sat $=\mathrm{C} 14: 0+\mathrm{C} 16: 0+\mathrm{C} 18: 0+\mathrm{C} 20: 0+\mathrm{C} 22: 0$

$\Sigma$ monounsat $=\mathrm{C} 16: 1+\mathrm{C} 18: 1+\mathrm{C} 20: 1$

$\Sigma$ polyunsat $=\mathrm{C} 18: 2+\mathrm{C} 18: 3$

$\mathrm{LSD}_{0.05}$, Least significance difference at the 0.05 probability level

ns, non-significant

Table 5 Descriptive statistics of mean biodiesel properties by genotype for TN07-93RR and AG3906 grown in Milan, TN, Springfield, TN, and Knoxville, TN in 2008 under two sodium selenate treatments: $0 \mathrm{mg} \mathrm{L}^{-1}$ (control) and $12 \mathrm{mg} \mathrm{L}^{-1}$ (high)

\begin{tabular}{|c|c|c|c|c|c|c|c|c|}
\hline \multirow[t]{2}{*}{ Genotype } & \multirow[t]{2}{*}{$\mathrm{AV}\left(\mathrm{mg} \mathrm{KOH} \mathrm{g}^{-1}\right)$} & \multicolumn{2}{|c|}{ Cold flow } & \multicolumn{2}{|c|}{ Oxidative stability } & \multirow[t]{2}{*}{$v\left(40^{\circ} \mathrm{C}, \mathrm{mm}^{2} \mathrm{~s}^{-1}\right)$} & \multirow[t]{2}{*}{ PV (meq kg ${ }^{-1}$ ) } & \multirow[t]{2}{*}{ IV $\left(\mathrm{g} \mathrm{I}_{2} 100 \mathrm{~g}^{-1}\right)$} \\
\hline & & $\mathrm{CP}\left({ }^{\circ} \mathrm{C}\right)$ & $\mathrm{PP}\left({ }^{\circ} \mathrm{C}\right)$ & IP $\left(110^{\circ} \mathrm{C}, \mathrm{h}\right)$ & OT $\left({ }^{\circ} \mathrm{C}\right)$ & & & \\
\hline AG3906 & 0.0 & 1.2 & -0.5 & 5.3 & 179.0 & 4.2 & 13.2 & 128.2 \\
\hline TN07-93RR & 0.0 & 1.3 & -0.5 & 7.4 & 184.1 & 4.3 & 7.6 & 113.8 \\
\hline $\mathrm{LSD}_{0.05}$ & ns & ns & ns & 1.3 & 1.9 & 0.1 & 4.8 & 0.9 \\
\hline
\end{tabular}

$\mathrm{LSD}_{0.05}$, Least significance difference at the 0.05 probability level

ns, non-significant

Table 6 Descriptive statistics of mean biodiesel properties by genotype and treatment for TN07-93RR and AG3906 grown in Milan, TN, Springfield, TN, and Knoxville, TN in 2008 under two sodium selenate treatments: $0 \mathrm{mg} \mathrm{L}^{-1}$ (control) and $12 \mathrm{mg} \mathrm{L}^{-1}$ (high)

\begin{tabular}{|c|c|c|c|c|c|c|c|c|c|}
\hline \multirow[t]{2}{*}{ Treatment } & \multirow[t]{2}{*}{ Genotype } & \multirow{2}{*}{$\begin{array}{l}\mathrm{AV} \\
\left(\mathrm{mg} \mathrm{KOH} \mathrm{g}^{-1}\right)\end{array}$} & \multicolumn{2}{|c|}{ Cold flow } & \multicolumn{2}{|c|}{ Oxidative stability } & \multirow[t]{2}{*}{$v\left(40^{\circ} \mathrm{C}, \mathrm{mm}^{2} \mathrm{~s}^{-1}\right)$} & \multirow{2}{*}{$\begin{array}{l}\text { PV } \\
(\text { meq kg } \\
-1)\end{array}$} & \multirow{2}{*}{$\begin{array}{l}\text { IV } \\
\left(\mathrm{g} \mathrm{I}_{2} 100 \mathrm{~g}^{-1}\right)\end{array}$} \\
\hline & & & $\mathrm{CP}\left({ }^{\circ} \mathrm{C}\right)$ & $\mathrm{PP}\left({ }^{\circ} \mathrm{C}\right)$ & IP $\left(110{ }^{\circ} \mathrm{C}, \mathrm{h}\right)$ & OT $\left({ }^{\circ} \mathrm{C}\right)$ & & & \\
\hline Control & AG3906 & 0.0 & 1.2 & -0.4 & 5.2 & 178.8 & 4.17 & 15.1 & 128.0 \\
\hline High & AG3906 & 0.0 & 1.2 & -0.6 & 5.5 & 179.2 & 4.18 & 11.2 & 128.3 \\
\hline Control & TN07-93RR & 0.0 & 1.3 & -0.3 & 7.7 & 183.6 & 4.35 & 6.9 & 113.7 \\
\hline High & TN07-93RR & 0.1 & 1.3 & -0.7 & 7.2 & 184.6 & 4.30 & 8.3 & 114.0 \\
\hline $\mathrm{LSD}_{0.05}$ & & ns & ns & ns & ns & ns & ns & ns & ns \\
\hline
\end{tabular}

$\mathrm{LSD}_{0.05}$, Least significance difference at the 0.05 probability level

ns, non-significant 
Table 7 Descriptive statistics of mean biodiesel properties by genotype and location for TN07-93RR and AG3906 grown in Milan, TN, Springfield, TN, and Knoxville, TN in 2008 under two sodium selenate treatments: $0 \mathrm{mg} \mathrm{L}^{-1}$ (control) and $12 \mathrm{mg} \mathrm{L}^{-1}$ (high)

\begin{tabular}{|c|c|c|c|c|c|c|c|c|c|}
\hline \multirow[t]{2}{*}{ Location } & \multirow[t]{2}{*}{ Genotype } & \multirow[t]{2}{*}{$\mathrm{AV}\left(\mathrm{mg} \mathrm{KOH} \mathrm{g} \mathrm{g}^{-1}\right)$} & \multicolumn{2}{|c|}{ Cold Flow } & \multicolumn{2}{|c|}{ Oxidative Stability } & \multirow{2}{*}{$\begin{array}{l}v\left(40{ }^{\circ} \mathrm{C},\right. \\
\left.\mathrm{mm}^{2} \mathrm{~s}^{-1}\right)\end{array}$} & \multirow{2}{*}{$\begin{array}{l}\text { PV } \\
\text { (mequiv kg }^{-1} \text { ) }\end{array}$} & \multirow{2}{*}{$\begin{array}{l}\text { IV }\left(\mathrm{g} \mathrm{I}_{2}\right. \\
\left.100 \mathrm{~g}^{-1}\right)\end{array}$} \\
\hline & & & $\mathrm{CP}\left({ }^{\circ} \mathrm{C}\right)$ & $\mathrm{PP}\left({ }^{\circ} \mathrm{C}\right)$ & IP $\left(110^{\circ} \mathrm{C}, \mathrm{h}\right)$ & $\mathrm{OT}\left({ }^{\circ} \mathrm{C}\right)$ & & & \\
\hline Knoxville, TN & AG3906 & 0.0 & 2.6 & 1.0 & 6.5 & 179.6 & 4.2 & 16.8 & 124.0 \\
\hline Knoxville, TN & TN07-93RR & 0.0 & 3.2 & 1.7 & 8.1 & 184.1 & 4.3 & 8.6 & 112.5 \\
\hline Springfield, TN & AG3906 & 0.0 & 0.8 & -1.0 & 4.7 & 178.0 & 4.2 & 12.4 & 131.5 \\
\hline Springfield, TN & TN07-93RR & 0.1 & 0.6 & -1.0 & 7.4 & 183.9 & 4.3 & 7.0 & 115.5 \\
\hline Milan. TN & AG3906 & 0.0 & 0.3 & -1.5 & 4.8 & 179.5 & 4.1 & 10.4 & 129.0 \\
\hline Milan. TN & TN07-93RR & 0.0 & 0.2 & -2.2 & 6.9 & 184.3 & 4.4 & 7.2 & 113.5 \\
\hline $\mathrm{LSD}_{0.05}$ & & ns & 0.3 & 0.5 & ns & ns & ns & ns & ns \\
\hline
\end{tabular}

$\mathrm{LSD}_{0.05}$, Least significance difference at the 0.05 probability level ns, non-significant

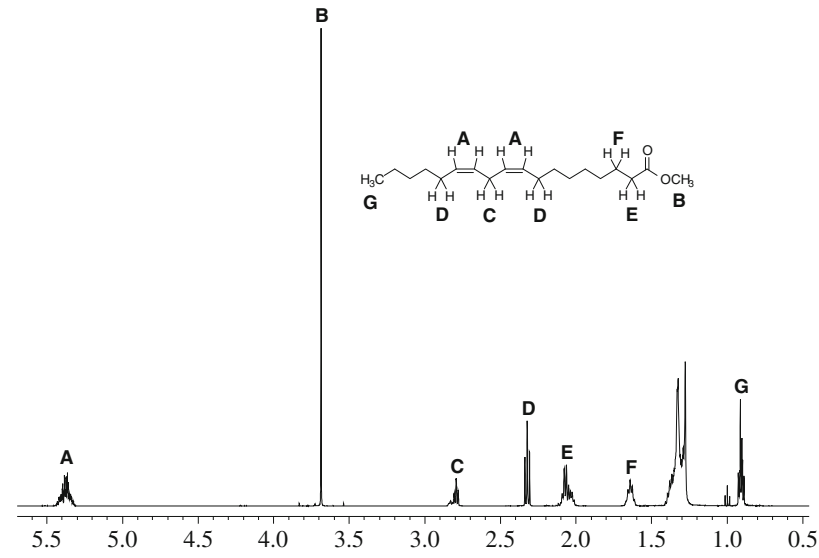

Fig. 1 Typical $500 \mathrm{MHz}{ }^{1} \mathrm{H}-\mathrm{NMR}$ spectrum $\left(\mathrm{CDCl}_{3}\right.$ solvent $)$ of soybean oil methyl esters. Methyl linoleate is shown for peak assignment convenience

$\left(<120 \mathrm{~g} \mathrm{I}_{2} 100 \mathrm{~g}^{-1}\right)$ and IP $(>6 \mathrm{~h})$ can be used to eliminate AG3906 from consideration as having the best fuel properties. AG3906 exceeded the maximum limit for IV (128.2) and did not meet the minimum specified IP limit $(5.3 \mathrm{~h})$. However, TN07-93RR was able to meet these requirements with IV and IP values of $113.8 \mathrm{~g} \mathrm{I}_{2} 100 \mathrm{~g}^{-1}$ and $7.4 \mathrm{~h}$, respectively.

FAME that are most appropriate for providing both acceptable oxidative stability and low temperature operability are the 16 and 18 carbon monounsaturated palmitoleic acid (C16:1) and oleic acid (C18:1) [23, 26]. As seen in Table 2, AG3906 contained the lowest percentage of monounsaturates $(\sim 25 \mathrm{wt} \%)$ and TN07-93RR contained the highest percentage of monounsaturates $(\sim 38 \mathrm{wt} \%)$. This in part explained the difference between the PVs of these samples, as higher PVs of relatively fresh samples are indicative of greater oxidative degradation.

The highest content of oleic acid that has been achieved by conventional breeding is $>70 \%$. However, the stability of the oleic content across environments has been a major

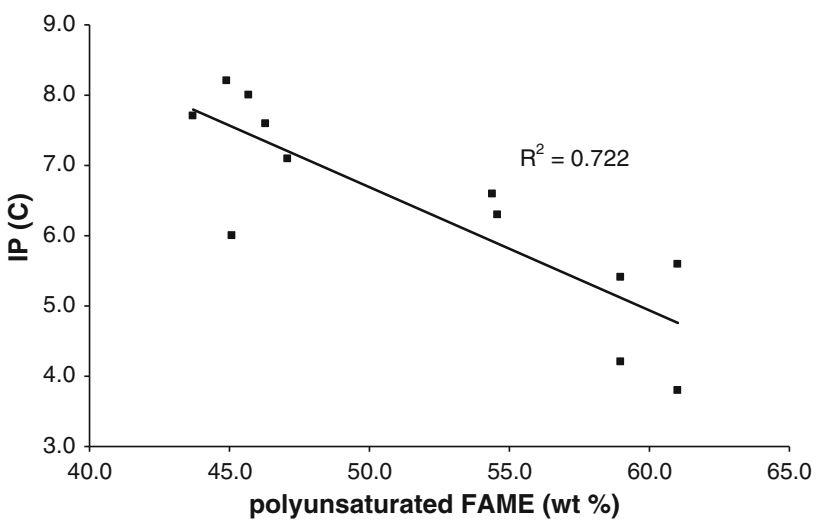

Fig. 2 Relationship between polyunsaturated FAME content (wt $\%$ ) and IP $\left(R^{2} 0.722\right)$

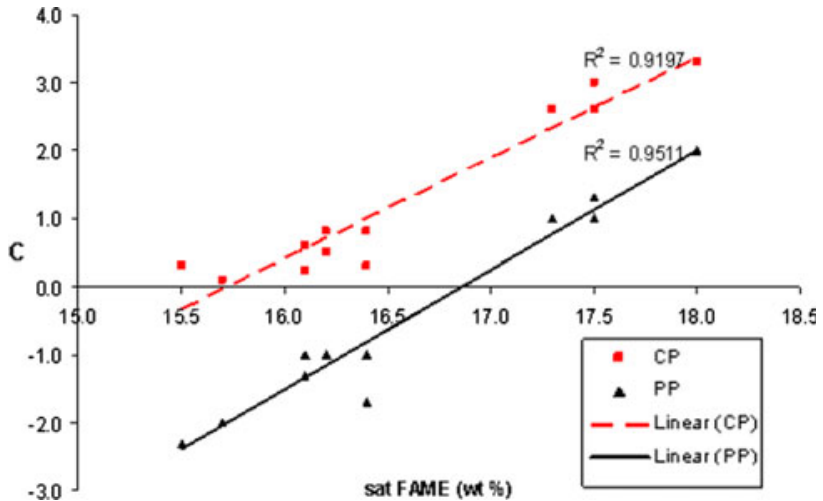

Fig. 3 Relationship between saturated FAME content (wt $\%$ ) and CP $\left(R^{2} 0.9197\right)$ and PP $\left(R^{2} 0.9511\right)$

consideration and the influence of the mid-oleic trait on agronomic and seed traits has yet to be determined. A soybean oil with $>80 \%$ oleic acid has been developed by the DuPont Company by inserting a second copy of the $F A D 2-1$ gene that silenced the gene that naturally occurs in the plant resulting in suppression of linoleate formation 
[28]. However, the genetic modification involved the use of the bla gene for ampicillin resistance as a selectable marker. Although the likelihood of transferring the bla gene from the high-oleic soybean to a microorganism in the environment was small, the soybean was pulled off the market. However, a newer cultivar with this level of oleic acid is likely to be commercialized within the next 2 years.

Generally, $\mathrm{CP}$ and PP values of less than $0{ }^{\circ} \mathrm{C}$ are desired. Lower values for $\mathrm{CP}$ and PP indicate greater resistance to fuel solidification when exposed to sub-ambient temperatures. Utilizing this arbitrary guideline, AG3906 and TN0793RR both had CP values equal to or greater than $1{ }^{\circ} \mathrm{C}$ (Table 5). Conspicuous among these samples were the comparatively elevated levels of saturated FAME content in the Knoxville, TN samples versus the other two locations (Table 7). AG3906 and TN07-93RR in Knoxville, TN contained greater than $17 \mathrm{wt} \%$ saturated FAME, whereas AG3906 and TN07-93RR from the other two locations contained less than $16.5 \mathrm{wt} \%$ of these constituents. Studies conducted by Primomo et al. [29] showed different factors affect different fatty acid profiles. Palmitic acid, a saturated fatty acid, were shown to be the most stable fatty acid in soybeans. On the other hand stearic acid, another saturated fatty acid, were shown to be the most subjective to environmental changes. Although this study was not designed to test the influence of environments on saturated fatty acid stability, comparisons can be made between saturated fatty acid levels and cold flow properties CP and PP.

Saturated FAME have higher melting points than unsaturated FAME, which results in poor low temperature properties. Figure 3 shows the strong relationship between saturated FAME content and CP $\left(R^{2} 0.9197\right)$ and PP $\left(R^{2}\right.$ 0.9511): more highly saturated FAME content resulted in higher (less desirable) CP and PP values.
Clemente et al. at the University of Nebraska-Lincoln [26] produced a soybean with high oleic acid $(>85 \%)$ and low saturated fatty acid $(<6 \%)$ content by down regulating two genes which increased oleic acid and decreased palmitic acid. It was developed from A3237 and the overall agronomics were not expected to be superior to current soybean cultivars. Additional agronomic improvements are currently being researched. They demonstrated an improvement in cold flow properties in comparison to conventional soybean oil. They reported conventional soybean oil had a CP of $-1{ }^{\circ} \mathrm{C}$ and a PP of $0{ }^{\circ} \mathrm{C}$ and the high oleic/low saturated fatty acid soybean cultivar had a $\mathrm{CP}$ of $-5{ }^{\circ} \mathrm{C}$ and a PP of $-9{ }^{\circ} \mathrm{C}$. This data supports the results obtained in this study showing that increases in oleic acid and lower saturated fatty acid content can lead to better cold flow performance.

Lastly, all samples were satisfactory with respect to KV, as all values were within the limits prescribed in ASTM D6751 and EN 14214. In addition, Se treatments had no effect on the biodiesel properties tested in this study (Table 6), which may suggest that there were insufficient concentrations of Se in the oil to affect biodiesel properties.

\section{Selenium Uptake}

To determine the ability of TN07-93RR and AG3906 to accumulate seed Se, both meal and oil components were analyzed using an ICP-MS (Tables 8, 9). AG3906 had significant differences between all Se treatments: control (4.50 mg L $\left.{ }^{-1}\right)$, low (5.81 $\left.\mathrm{mg} \mathrm{L}^{-1}\right)$, medium $\left(8.05 \mathrm{mg} \mathrm{L}^{-1}\right)$ and high $\left(9.86 \mathrm{mg} \mathrm{L}^{-1}\right)$. AG3906 had an average Se increase of $1.79 \mathrm{mg} \mathrm{L}^{-1}$ between each treatment. The greatest Se accumulation occurred between the low $\left(5.81 \mathrm{mg} \mathrm{L}^{-1}\right)$ and medium $\left(8.05 \mathrm{mg} \mathrm{L}^{-1}\right)$ treatments, with a $2.24 \mathrm{mg} \mathrm{L}^{-1}$

Table 8 Descriptive statistics of Se uptake in the meal by genotype and treatment for TN07-93RR and AG3906 grown in Milan, TN, Springfield, TN, and Knoxville, TN in 2008 under four sodium selenate treatments: $0 \mathrm{mg} \mathrm{L}^{-1}$ (control), $3 \mathrm{mg} \mathrm{L}^{-1}$ (low), $6 \mathrm{mg} \mathrm{L}-1$ (medium) and $12 \mathrm{mg} \mathrm{L}^{-1}$ (high)

\begin{tabular}{|c|c|c|c|c|c|c|c|c|c|c|}
\hline Genotype & Treatment & Boron & Magnesium & Phosphorus & Potassium & Calcium & Manganese & Copper & Zinc & Selenium \\
\hline AG3906 & Control & 28.30 & $5,935.56$ & $11,118.52$ & $42,174.07$ & $7,078.89$ & 103.14 & 44.43 & 128.01 & 4.50 \\
\hline AG3906 & Low & 39.20 & $8,570.37$ & $15,999.63$ & $53,214.81$ & $7,047.41$ & 154.40 & 57.77 & 145.18 & 5.81 \\
\hline AG3906 & Med & 29.93 & $5,886.30$ & $11,092.22$ & $42,018.52$ & $6,928.89$ & 109.58 & 43.48 & 129.93 & 8.05 \\
\hline AG3906 & High & 34.02 & $7,582.59$ & $13,945.93$ & $47,829.63$ & $6,492.96$ & 140.67 & 46.38 & 130.68 & 9.86 \\
\hline TN07-93RR & Control & 25.53 & $6,047.41$ & $10,703.70$ & $37,104.07$ & $6,732.96$ & 88.56 & 44.40 & 125.95 & 4.56 \\
\hline TN07-93RR & Low & 24.92 & $5,947.41$ & $10,358.89$ & $36,023.33$ & $6,784.81$ & 84.66 & 43.38 & 118.49 & 5.67 \\
\hline TN07-93RR & Med & 26.30 & $5,935.56$ & $10,452.59$ & $36,356.67$ & $6,446.30$ & 83.00 & 44.32 & 122.86 & 7.01 \\
\hline TN07-93RR & High & 26.08 & $5,956.67$ & $10,484.81$ & $36,332.59$ & $6,422.59$ & 84.14 & 44.63 & 123.66 & 9.83 \\
\hline $\operatorname{LSD}_{0.05}$ & & ns & ns & ns & ns & ns & ns & ns & ns & 1.25 \\
\hline
\end{tabular}

$\mathrm{LSD}_{0.05}$, Least significance difference at the 0.05 probability level

ns, non-significant

Values are reported as $\mathrm{mg} \mathrm{L}^{-1}$ 
Table 9 Descriptive statistics of Se uptake in the oil by genotype and treatment for TN07-93RR and AG3906 grown in Milan, TN, Springfield, $\mathrm{TN}$, and Knoxville, TN in 2008 under two sodium selenate treatments: $0 \mathrm{mg} \mathrm{L}^{-1}$ (control) and $12 \mathrm{mg} \mathrm{L}^{-1}$ (high)

\begin{tabular}{lllllllllll}
\hline Genotype & Treatment & Boron & Magnesium & Phosphorus & Potassium & Calcium & Manganese & Copper & Zinc & Selenium \\
\hline AG3906 & Control & 4.94 & 9.03 & 248.07 & 81.42 & 214.98 & 0.11 & 0.50 & 0.61 & 0.08 \\
AG3906 & High & 4.78 & 11.67 & 263.53 & 87.41 & 251.03 & 0.13 & 0.51 & 0.65 & 0.21 \\
TN07-93RR & Control & 4.64 & 11.87 & 244.27 & 73.16 & 258.40 & 0.14 & 0.74 & 0.68 & 0.03 \\
TN07-93RR & High & 5.04 & 9.15 & 265.60 & 67.67 & 245.00 & 0.10 & 0.53 & 0.49 & 0.28 \\
LSD $_{0.05}$ & & $\mathrm{~ns}$ & $\mathrm{~ns}$ & $\mathrm{~ns}$ & $\mathrm{~ns}$ & $\mathrm{~ns}$ & $\mathrm{~ns}$ & $\mathrm{~ns}$ & $\mathrm{~ns}$ & 0.15 \\
\hline
\end{tabular}

$\mathrm{LSD}_{0.05}$, Least significance difference at the 0.05 probability level

ns, non-significant

Values are reported as $\mathrm{mg} \mathrm{L}^{-1}$

increase in Se. TN07-93RR had significant differences between Se treatments low, medium and high: low (5.67 $\left.\mathrm{mg} \mathrm{L}^{-1}\right)$, medium $\left(7.01 \mathrm{mg} \mathrm{L}^{-1}\right)$ and high $\left(9.83 \mathrm{mg} \mathrm{L}^{-1}\right)$. TN07-93RR had an average Se increase of $1.76 \mathrm{mg} \mathrm{L}^{-1}$ between the low, medium, and high treatments. The greatest Se accumulation occurred between the medium (7.01 $\left.\mathrm{mg} \mathrm{L}^{-1}\right)$ and high $\left(9.83 \mathrm{mg} \mathrm{L}^{-1}\right)$ treatments, with a $2.82 \mathrm{mg} \mathrm{L}^{-1}$ increase in Se. These results show that it is possible to increase Se levels in soybean meal using foliar Se applications and higher $\mathrm{Se}$ treatments result in greater increases in Se. The addition of Se to the soybean market could not only offer added health benefits, but it may also allow Se to be established into an already well-developed market.

In the oil, there were only significant differences in TN07-93RR $(P<0.0001)$ for Se concentrations among Se treatments. TN07-93RR showed an increase of $0.15 \mathrm{mg} \mathrm{L}^{-1}$ between the control $\left(0.03 \mathrm{mg} \mathrm{L}^{-1}\right)$ and the high $\left(0.28 \mathrm{mg} \mathrm{L}^{-1}\right)$ Se treatment.

In a study by Kopsell et al. [30], plants of rapid-cycling Brassica oleracea population were grown in nutrient solutions with sodium selenate $\left(\mathrm{Na}_{2} \mathrm{SeO}_{4}\right)$ concentrations: $0,1.0,2.0,3.0,4.0,5.0,6.0$, and $7.0 \mathrm{mg} \mathrm{Na}_{2} \mathrm{SeO}_{4} \mathrm{~L}^{-1}$. Se concentration in the seeds and in the leaf tissue increased linearly with $\mathrm{Na}_{2} \mathrm{SeO}_{4}$ concentrations. However, the $\mathrm{Se}$ level in the leaf tissue was higher than in the seed tissue at each Se treatment level.

Zhang et al. [9] found that a greater Se level in seed grains comes not only from the forms of Se supplied, but from genotype differences. Time and concentration sequential experiments were carried out to study the accumulation and transport of two Se species, selenite and selenate, by soybean seedlings of two cultivars, Tong-ai (TA) and Qidong Green-skin (QG). Soybean seedlings were transplanted into a modified basic Hoagland solution, which contained $0.2,2,5,10,20,50$, and $100 \mu \mathrm{M}$ Se as selenite or selenate, respectively. Comparatively, TA had a consistently higher Se concentration than QG both in the roots and shoots under selenate. This confirms Se is not evenly distributed in plant tissues and plant species differ greatly in their ability to accumulate Se. This should be taken into account for selecting high Se-accumulating plants and plants that are able to accumulate high levels of $\mathrm{Se}$ into the oil to improve $\mathrm{Se}$ benefits to the biodiesel industry.

Soybean crops have a much higher Se concentration than cereal or forage crops and Se concentrations in soybean seeds vary significantly with their different genotypes [30]. Since the greatest increase in Se came from the highest foliar treatment in the increased oleic acid genotype, foliar applications of Se may have the greatest effect on soybeans with elevated oleic acid levels. Oleic acid is an Omega 9 fatty acid and has been shown to lower the risk of a heart attack, arteriosclerosis, and aid in cancer prevention. This in combination with the antioxidant role of Se could improve the overall health benefits of consuming soy products. Future research is needed to study more thoroughly the effects of $\mathrm{Se}$ on increased oleic acid soybean lines.

Acknowledgments We appreciate the support provided by the University of Tennessee Agricultural Experiment Station and the Tennessee Soybean Promotion Board. We also appreciate the support by the Better Bean Initiative of the United Soybean Board, which led to the development of the increased oleic soybean lines that made this research possible. The authors acknowledge Benetria N. Banks and Ray K. Holloway for their excellent technical assistance.

\section{References}

1. Knothe G (2008) "Designer" biodiesel: optimizing fatty ester composition to improve fuel properties. Energy Fuels 22:1358-1364

2. Moser BR (2009) Biodiesel production, properties, and feedstocks. In vitro Cell Dev Biol-Plant 45:229-266

3. Knothe G, Van Gerpen J, Krahl J (2010) The biodiesel handbook, 2nd edn. AOCS Press, Champaign

4. Frankel EN (2005) Lipid oxidation, 2nd edn. The Oily Press, Bridgewater

5. Das NP, Pereira TA (1990) Effect of flavonoids on thermal autoxidation of palm oil; structural activity relationships. J Am Chem Soc 67:255-258

6. Fallen B (2009) Soybean enhancement for improved biodiesel production. M.S. Thesis, University of Tennessee 
7. Iqbal S, Bhanger MI (2007) Stabilization of sunflower oil by garlic extract during accelerated storage. Food Chem 100:246254

8. Mayland HF (1994) Selenium in animal and plant nutrition. Selenium in the environment. Marcel Dekker, New York

9. Zhang Y, Pan G, Chen J, Hu Q (2003) Uptake and transport of selenite and selenate by soybean seedlings of two genotypes. Plant Soil 253:437-443

10. Burton JW, Wilson RF, Rebetzke GJ, Pantalone VR (2006) Registration of N98-4445A mid-oleic soybean germplasm line. Crop Sci 46:1010-1012

11. American Oil Chemists Society (AOCS) (1999) Oil content: Soxhlet extraction. Official methods and recommended practices of the American Oil Chemists Society, 5th edn. AOCS, Champaign Method $\mathrm{Ba}$ 3-38

12. Moser BR, Haas MJ, Winkler JK, Jackson MA, Erhan SZ, List GR (2007) Evaluation of partially hydrogenated methyl esters of soybean oil as biodiesel. Eur J Lipid Sci Technol 109:17-24

13. Freedman B, Pryde EH, Mounts TL (1984) Variables affecting the yields of fatty esters from transesterified vegetable oils. J Am Oil Chem Soc 61:1638-1643

14. American Oil Chemists Society (AOCS) (1999) Fatty acid composition by gas chromatography. Official methods and recommended practices of the American Oil Chemists Society, 5th edn. AOCS, Champaign Method Ce 1-62

15. American Oil Chemists Society (AOCS) (1999) Preparation of methyl esters of fatty acids. Official methods and recommended practices of the American Oil Chemists Society, 5th edn. AOCS, Champaign Method Ce 2-66

16. Knothe G, Kenar JA (2004) Determination of the fatty acid profile by ${ }^{1} \mathrm{H}-\mathrm{NMR}$ spectroscopy. Eur J Lipid Sci Technol 106:88-96

17. American Society for Testing and Materials (ASTM) (2007) Standard test method for cloud point of petroleum products (constant cooling rate method). Annual book of ASTM standards. ASTM Press, West Conshohocken Method D5773

18. American Society for Testing and Materials (ASTM) (2001) Standard test method for pour point of petroleum products (automatic pressure pulsing method). Annual book of ASTM standards. ASTM Press, West Conshohocken Method D5949

19. American Society for Testing and Materials (ASTM) (2006) Standard test method for kinematic viscosity of transparent and opaque liquids (and calculation of dynamic viscosity). Annual book of ASTM standards. ASTM Press, West Conshohocken Method D445

20. European Committee for Standardization (CEN) (2009) Fat and oil derivatives-fatty acid methyl esters (FAME)-determination of oxidative stability (accelerated oxidation test). European Committee for Standardization Press, Brussels Method EN 14112:2008

21. American Oil Chemists Society (AOCS) (1999) Acid value. Official methods and recommended practices of the American Oil Chemists Society, 5th edn. AOCS Press, Champaign Method Cd 3d-63

22. American Oil Chemists Society (AOCS) (1999) Calculated iodine value. Official methods and recommended practices of the American Oil Chemists Society, 5th edn. AOCS Press, Champaign Method Cd 1c-85

23. Shantha NC, Decker EA (1994) Rapid, sensitive, iron-based spectrophotometric methods for determination of peroxide values of food lipids. J AOAC Int 77:421-424

24. Kopsell DA, Sams CE, Barickman CT, Deyton DE, Kopsell DE (2009) Selenization of basil and cilantro through foliar applications of selenate-Se and selenite-Se. Hortic Sci 44(2):438-442

25. U.S. Environmental Protection Agency (1996) Microwave assisted acid digestion of siliceous and organically based matrices, Method \#3052

26. Clemente TE, Kinney AJ (2005) Modifying soybean oil for enhanced performance in biodiesel blends. Fuel Process Technol 86:1137-1147

27. Rashid U, Anwar F, Moser BR, Knothe G (2008) Moringa oleifera oil: a possible source of biodiesel. Bioresour Technol 99:8175-8179

28. Alt JL, Fehr WR, Welke GA, Shannon JG (2005) Transgressive segregation for oleate content in three soybean populations. Crop Sci 45:2005-2007

29. Primomo V, Falk DE, Ablett GR, Tanner JW, Rajcan I (2002) Genotype $\times$ environment interactions, stability and agronomic performance of soybean with altered fatty acid profiles. Crop Sci 42:37-44

30. Kopsell DA, Kopsell DE, Randle WM (2003) Seed germination response of rapid-cycling Brassica oleracea grown under increasing sodium selenate. J Plant Nutr 26:1355-1366 